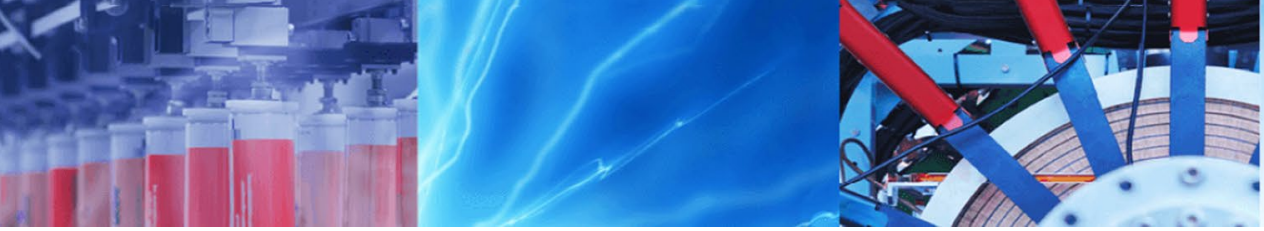

Research Article

\title{
Uncertainty analysis of climate change potential assessments of five building energy renovation measures in Sweden
}

\author{
Karin Farsäter $^{1}$ [D . Åsa Wahlström ${ }^{1}$. Dennis Johansson ${ }^{1}$
}

Received: 24 June 2021 / Accepted: 18 October 2021

Published online: 12 November 2021

(c) The Author(s) 2021 OPEN

\begin{abstract}
The aim of this study is to assess the impact of the uncertainties of life cycle inventory $(\mathrm{LCl})$ data for energy use and materials in life cycle assessments of standard energy renovation measures carried out in multi-family buildings in Sweden. Five energy renovation measures were assessed with regard to their climate change potential. Modules A1-A3 and module B6 were included in the assessment and the functional unit, $1 \mathrm{~m}^{2}$ heated floor area of a renovated building fulfilling the Swedish building regulations and with a calculation period of 20 years, was used. The uncertainty of $\mathrm{LCl}$ data for materials and energy were assessed using the Ecoinvent data quality system. This study shows that with two different energy mixes, all renovation measures result in a decrease in the climate change potential. The five renovation measures used in the simulations, with and without consideration to uncertainties, show a lower climate change potential when carried out than when not carried out. It is also shown in this study that the inclusion of the uncertainties of the input data did not have any impact on the overall decisions to renovate or not to renovate. However, this should not be regarded as a general conclusion. If a renovation measure were to have a higher level of material use, or if the "Future energy mix" were to be improved, uncertainty considerations could become much more important from a climate change perspective.
\end{abstract}

\section{Article Highlights}

- All assessed energy renovation measures show a decrease in their climate change potential when carried out.
- The energy renovation measures with the largest decreases of climate change potential are also the measures with largest energy saving potential.

- When uncertainties are considered, there are no overlaps in the results when carrying out or not carrying out a renovation measure.

Keywords Monte Carlo · LCA · Greenhouse gas emissions · Refurbishment · Energy efficiency $\cdot$ LCl input data

Supplementary Information The online version contains supplementary material available at https://doi.org/10.1007/s42452-02104838-4.

Karin Farsäter, karin.farsater@hvac.Ith.se | ${ }^{1}$ Department of Building and Environmental Technology, Division of Building Services, Lund University, 22100 Lund, Sweden. 


\section{Introduction}

The European Commission has published a "Renovation wave" strategy to boost renovation throughout the European Union (EU) as part of a larger strategy to reduce energy use and greenhouse gas emissions from the building sector [1]. The emission of greenhouse gas has a potential impact to change our climate. With the construction and real estate sectors having been found to be among the greatest contributors to greenhouse gas emissions, there is potential for improvement in these sectors [2]. The EU aims to be the first net climate-neutral continent by 2050 [3]. This goal will be fulfilled by lowering the emissions of all greenhouse gases and climate compensating for the remaining emissions. To assess greenhouse gas emissions, the use of life cycle assessment (LCA) methods to assess the climate change potential has increased in the construction and real estate sectors [4].

In Sweden, the construction and real estate sectors account for $18 \%$ of the country's greenhouse gas emissions [5] and it will, therefore, be mandatory from 2022 to provide climate declarations for newly constructed buildings [6]. This is seen as a possible way both to increase awareness of the impact of the climate change potential of our buildings and to gather data regarding appropriate levels of greenhouse gas emissions for future regulations. The regulations state that the climate declarations for buildings should be carried out from a life cycle perspective.

LCA is a standardised method (EN ISO 14044:2006) for assessing the environmental impact of a product or service throughout its life cycle [7]. The method can be used to identify opportunities for reducing the environmental impact of a product or service during different stages of its life cycle. The LCA standard provides overall guidance when carrying out an LCA [8]. The standard enables a high level of adaptability and flexibility for each assessment that is carried out. The standard does not specify which tool, database, functional unit or life cycle stages should be included in the assessment. To be able to assess results and compare different studies, the standard requires a high level of transparency in the LCA. The EN 15,978 standard allows an LCA to be used in a building perspective and provides definitions for LCA terminology when used in the building industry. In EN15978, the life cycle of a building is divided into four main stages: the A stage covers the manufacture of the building materials (modules $A 1-A 3$ ), their transportation to the building site (module A4) and the construction of the building (module A5); the use stage (modules B1-B7); the end-of-life cycle stage (modules (1-C4) and the optional benefits and loads beyond the system boundaries, the $D$ stage.
When carrying out an LCA there are two types of life cycle inventory (LCI) data that can be used, namely generic data and manufacturers' average or specific data [9]. Generic data can be found in large databases from, for example, a region (Europe) or in LCA software. These data can be average data either for a specific product or service for the relevant region or for a specific product group. Manufacturers' average or specific data are generated by the manufacturer of a specific product. This type of data can be presented in a product's environmental product declaration (EPD). An EPD can be published by the manufacturers themselves or be registered and validated by a third-party organisation (EPD type III). The information that can be found in an EPD for a building component is usually for the product and construction stages (modules A1-A5) and waste processing in its end-of-life stage (module C3). Sometimes the D stage information is also included.

As a consequence of the "Renovation wave" strategy mentioned above, the use of LCAs when renovating buildings is also expected to increase. LCA methods have previously been studied and used in research into different packages of renovation measures in buildings [4, 10-17]. The most common assessments carried out with regard to renovation measures concern the balance between the environmental impact of the embodied energy (modules $\mathrm{A} 1-\mathrm{A} 3$ ) of the additional materials used during the renovation and the operational energy (module B6) required during the use of the building, with or without the renovation being carried out [4]. Vilches, Garcia-Martinez and Sanchez-Montañes [4] also discuss how the distribution of the impact between the manufacture and use stages has changed. With more energy-efficient buildings, as a result of renovation measures, environmental impacts have decreased in the use stage and increased the manufacturing stage. This is due to the decreased energy demands in the buildings and the increase in the amounts of materials used.

Generally, in LCAs, there are several sources of uncertainties, for example, cumulative effects of model imprecisions, input uncertainties and data variability [18]. There is also an uncertainty in the results of an LCA due to the fact that most LCAs do not take into account location and point in time of the environmental impacts (emissions). Lately, several studies have been carried out that show the effects of the uncertainties. For example, the Scrucca et al. (2020) study shows that variations in results could be due to the person carrying out the LCA. Another example is the Emami et al. [20] study that shows that the choice of software and database can influence the results even when LCAs are carried out by the same person. Furthermore, in LCA studies of newly constructed buildings, the impact of the choice of inventory database ( $\mathrm{LCl}$ data), 
system boundary definition, replacement scenarios and building reference period were analysed by Häfliger et al. [21]. They concluded that the choices made when carrying out an LCA study can have significant impacts on the results. In the comparisons of different sources of $\mathrm{LCl}$ data for a whole building, they found an approximately $20 \%$ difference between the results when using $\mathrm{LCl}$ data from different databases. Similar conclusions were drawn by Morales et al., (2020) when assessing different painting and plastering options for a brick building.

Sensitivity analysis can be carried out using parameter studies or regression studies [23]. In a parameter study, the input value of one parameter is varied by setting alternative values and carrying out a single assessment per chosen input value. In a regression study, one main minimum and one main maximum value are set for each parameter as well as a distribution. As a case study, different types of sensitivity analysis methods were assessed by Pannier, Schalbart and Peuportier [24] for a whole building that had fulfilled the passive house criteria. The study concluded that the methods for carrying out sensitivity analyses performed well in the context of an LCA. This conclusion is further supported by Pomponi, D'Amico and Moncaster [25] in their analysis of the embodied energy of building materials in an improved method for sensitivity analysis based on Monte Carlo simulations.

However, detailed sensitivity analyses of the influence of uncertainties in $\mathrm{LCl}$ data for individual energy renovation measures are lacking. Consideration of the uncertainties of $\mathrm{LCl}$ data and carrying out Monte Carlo simulations are not assessed in detail for individual energy renovation measures.

\subsection{Aim}

The aim of this study is to assess the impact the uncertainties of life cycle inventory (LCI) data for energy and materials in a life cycle assessment of standard energy renovation measures carried out in multi-family buildings in Sweden. This is done by assessing the impact of five individual renovation measures on their climate change potential.

\subsection{Research question}

What are the effects of including uncertainties in life cycle inventory $(\mathrm{LCl})$ data in an environmental assessment of energy renovation measures?

\section{Method}

Five energy renovation measures were assessed with regard to their impact on the climate change potentials with uncertainties being assessed for each $\mathrm{LCl}$ source of material and energy. The life cycle inventory $(\mathrm{LCl})$ data were assessed for its relevance for each renovation measure. The uncertainties were evaluated using the Ecoinvent data quality system and Monte Carlo simulations were performed.

\subsection{Assessed renovation measures}

Renovation measures carried out in two existing buildings were used as case studies. Input data, such as types of materials used, amounts of materials, differences in energy needs for heating before and after renovation, and building size, were gathered from the two buildings. In one of them, the buildings' ventilation systems were renovated, and in the other, renovations were carried out on the envelopes of the building. In both cases, multi-family buildings built at the end of the 1960s and connected to the town's district heating system were studied. The buildings were chosen for this study as they had already been monitored in previous research projects in which information about the renovation work had been gathered and was available for use in this study [26-28].

In the building where the ventilation system was renovated, the renovation was monitored by a research team whose main purpose was to observe the energy needs before and after renovation as well as the residents' perceived level of indoor environmental quality. In order to evaluate the specific effect of installing a heat recovery system in the ventilation system, this was the only renovation measure that was carried out in the buildings. Before renovation, there had been two different original ventilation systems in the buildings [26]. The building is situated in the mid-south of Sweden with a floor area of $991 \mathrm{~m}^{2}$ and has a heating energy need, prior to the renovation, of 131 $\mathrm{kWh} / \mathrm{m}^{2}$ (heated floor area).

The building where the renovation measures on the building envelope was carried out is one of the neighbourhoods comprised of 14 almost identical buildings in the south of Sweden. The research team monitoring the renovation was a transdisciplinary team that focused on the residents' perceived indoor environment. Measurements of indoor environment parameters before and after carrying out the renovation work were also recorded [27-30]. The building that is used in this study has a floor area of $2515 \mathrm{~m}^{2}$ and a heating energy need of $138 \mathrm{kWh} /$ $\mathrm{m}^{2}$ (heated floor area). 
All the renovation measures that were assessed in this study are presented in Table 1 together with the corresponding added materials and differences in energy use as a result of the measures. Each renovation measure is assessed as a separate case study. The measures that were carried out in these buildings were chosen to sustain or improve their functions for the residents or to decrease the maintenance or energy use of the buildings. All the measures are commonly used in Sweden when renovating buildings to improve energy use [31].

The lifespans of the components used for the renovation work were assessed using the methodology described in ISO 15686-2:2012 and ISO 15686-8:2008. Different sources were used for different components and each source was evaluated regarding its relevance for the analysis as well as for each case study. In the case of the building envelope measures, the added materials for the attic insulation, doors, windows and wall replacements all had expected lifespans of 30 years as assumed in EN 15,459:2007.

According to the American Society of Heating, Refrigerating and Air-Conditioning Engineers (ASHRAE), the expected lifespan of fans and dampers is about 20 years. Diffusers, grilles and ductwork have an expected lifespan of 27-30 years [33]. The expected lifespan of an air handling unit (AHU) is 20 years [38]. In this study, the lifespans of the newly installed air handling unit (AHU) and the existing ducts are assumed to be 20 years. The new duct system is assumed to have a lifespan of 30 years, and supply air devices are assumed to have a lifespan of 25 years, according to the manufacturer [35]. After 20 years, it is assumed that the ventilation system will need a major overhaul or parts will need to be replaced to prolong the system's lifespan.

The ambition in this study is to include all materials needed for each renovation case in the assessment. Some of the products used, such as doors, contain small amounts of materials that constitute less than one per cent of the whole product and these materials have, therefore, not been included.

\subsection{Assessing the potential environmental impact}

To assess the potential environmental impact of the renovation measures, the study investigates life cycle assessments (LCAs) of each renovation measure individually. The EN 15,978 standard has been followed for the overall structure of the study as well as its terms and definitions. How the standard has been used is presented in this section, for example, regarding the setting of boundaries for the different life cycle stages.

The LCAs only assess the parts of the renovation measures that influence the energy efficiency of the buildings.
None of the renovation measures that were carried out due to technical faults or maintenance were assessed. The assessment includes the differences in energy needs for heating the buildings when carrying out and not carrying out a particular renovation measure as well as the effects of the added materials used in the renovation measures that influence the energy efficiency.

The environmental impact of the renovation measures that are assessed in this study is their climate change potential. Climate change potential refers to the potential impact that greenhouse gas emissions have on increasing the temperature on land and in waters [9].

The LCAs were carried out using OpenLCA (version 1.9.0) software. OpenLCA was developed, and is maintained, by the German company Green Delta. The software provides an interface that links different databases of potential environmental impacts of products and services with different methods of assessing their environmental impact [39]. The tool was first developed to assess environmental impact by performing an LCA but it is now also possible to include economic and social aspects. Different LCA tools were evaluated in Farsäter (2019). Their study showed that it could be possible to carry out an uncertainty analysis in the OpenLCA tool.

In the OpenLCA software, the ILCD 2011 Midpoint v.1.0 (version 1.5.7) method was chosen for the calculations [41]. The environmental impact category used in this method is called "Climate change - ILCD 2011 Midpoint". ILCD uses the IPCC2007 GWP100 model for climate change assessments but adds the emissions from the stratosphere, non-urban air and the ground from the ReCiPe2008.

\subsubsection{System boundaries}

According to EN15978, some of the renovation measures treated in this study could be included in module B4, replacement. For example, the replacement of windows. Other measures could be included in module B5, refurbishment, that states that any major change can be included in this module. The assessed renovation measures in this study were interpreted as major changes to a building's envelope or ventilation and are, therefore, treated as belonging to module B5. EN 15,798 also states that, when renovation is carried out in a building and it has never been included in an earlier assessment of the building, as is the case in this study, the environmental impacts are to be allocated to the A1-A5 modules.

The climate change potential of the energy renovation measures includes the following life cycle stages (according to EN15978):

1. Production of the additional material for the building (modules A1-A3) 


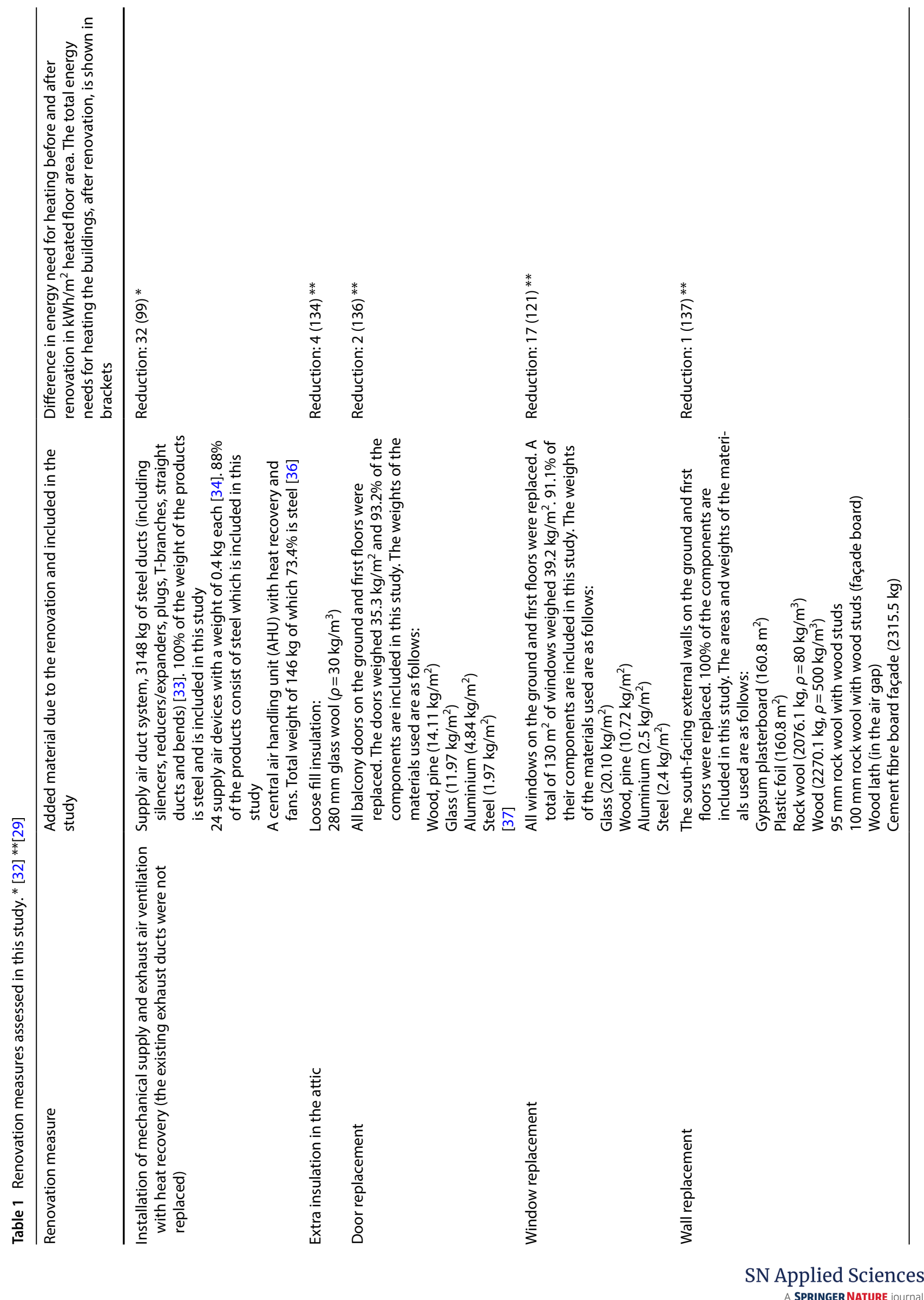


2. The operational energy reduction of the building (module B6).

The study does not include the potential environmental impact of workmanship, any materials related to the installation stage (module A5), any other part of the use stage, such as filter changes, except the energy use (module B6), any waste treatment (stage $C$ ) nor any benefits (stage $D$ ). Stage $C$ is excluded from the study as it only has a small impact compared to stage $A$ and module $B 6$ according to earlier studies [42]. In an LCA, stage D is optional according to the LCA standard [43].

The functional unit of the study is $1 \mathrm{~m}^{2}$ heated floor area of a renovated building that fulfils the Swedish building regulations. It is assumed that the renovation measures carried out will prolong the building's lifespan by approximately 20 years. A calculation period of 20 years was used in this study (2020-2040). After this period, new decisions regarding further measures will have to be assessed.

\subsubsection{Data for materials}

In this study, the free European reference, the Life Cycle Database of the Joint Research Center version 3.2 (ELCD), is used for $\mathrm{LCl}$ information regarding materials and energy sources. Using the OpenLCA software, it is also possible to create an equivalent product or service by using different raw materials and specifying their emissions and impacts [40].

Data for the materials used in the different renovation measures were primarily chosen from the materials that were available in the database. When the required materials were not available in the database, values for the raw materials in the products were combined using existing sources in the database. The total embodied energy was then calculated by combining data from different external sources.
- The total embodied energy for the ventilation ducts was taken from an EPD carried out on a ventilation duct [44]. This value of total embodied energy was used for the different ventilation components (supply devices, ventilation ducts and air handling unit) [45].

- The quantities of different materials used for the doors and windows, and the total embodied energy for the doors and windows, were gathered from EPD carried out for a door and a window [37]. The EPD was chosen for their similarities to the doors and windows used in the renovation.

\subsubsection{Energy mix}

In this study, the energy sources for heating the buildings are based on the average mix of sources used today in district heating systems in Sweden [46]. Two different energy mix scenarios were used in this study. One of the future scenarios assumes that the energy mix will not change from what it is today. This scenario is referred to as "Today's energy mix". The other scenario is called "Future energy mix" and is based on two assumptions:

1. There will be no fossil fuels in the energy mix for heating by 2050 [47]. This will lead to an increase in heating provided by electricity and biofuels but with an unchanged use of waste incineration and natural gas.

2. That Europe will tend towards today's emission levels of the Swedish electricity mix. The European electricity mix will, in the simulations, be replaced by the Swedish electricity mix.

The "Future energy mix" has been assumed to improve from 2020, with today's energy mix for heating and electricity tending towards the two assumptions as illustrated in Fig. 1.

The proportions of different energy sources in the two scenarios are presented in Table 2. Appropriate equivalents
Fig. 1 How the energy scenario "Future energy mix" is assumed to improve the mix of energy sources in the district heating system

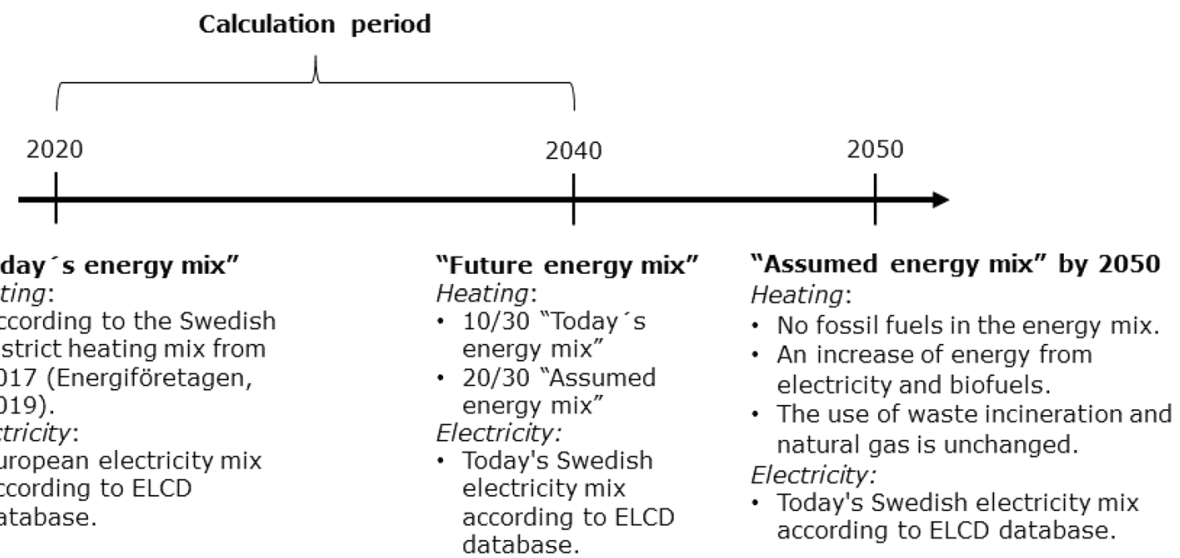


Table 2 Proportions of different energy sources considered in this study. *allocated to the main production process

\begin{tabular}{|c|c|c|c|c|}
\hline $\begin{array}{l}\text { Energy source (district } \\
\text { heating) }\end{array}$ & $\begin{array}{l}\text { Proportions in } \\
\text { "Today's energy } \\
\text { mix" (\%) }\end{array}$ & $\begin{array}{l}\text { Proportions in the } \\
\text { assumed energy mix by } \\
2050(\%)\end{array}$ & $\begin{array}{l}\text { Proportions in the "Future } \\
\text { energy mix", averaged dur- } \\
\text { ing 2020-2040 (\%) }\end{array}$ & Resource used in OpenLCA \\
\hline Biofuels (e.g. pellets) & 41.4 & 45.1 & 42.63 & $\begin{array}{l}\text { Heat, consumption mix, at } \\
\text { consumer, residential heat- } \\
\text { ing systems from wood pel- } \\
\text { lets, boiler, max. heat output } \\
14.9 \mathrm{~kW} \text {, at a temperature } \\
\text { level of } 70^{\circ} \mathrm{C} \text { adjusted to } \\
\text { exclude biogenic carbon }\end{array}$ \\
\hline Waste incineration & 22.0 & 22.0 & 22 & $\begin{array}{l}\text { Waste incineration of munici- } \\
\text { pal solid waste (MSW), at } \\
\text { plant, average European } \\
\text { waste-to-energy plant, with- } \\
\text { out collection, transport and } \\
\text { pre-treatment - EU-27 }\end{array}$ \\
\hline Oil & 1.2 & 0 & 0.8 & $\begin{array}{l}\text { Process steam from light fuel } \\
\text { oil, consumption mix, at } \\
\text { plant, heat plant, MJ - SE }\end{array}$ \\
\hline Electricity & 9.4 & 10.2 & 9.67 & $\begin{array}{l}\text { Electricity grid mix } 1 \mathrm{kV}-60 \mathrm{kV} \text {, } \\
\text { consumption mix, at con- } \\
\text { sumer, AC, } 1 \mathrm{kV}-60 \mathrm{kV}- \\
\text { EU-27 } \\
\text { And } \\
\text { Electricity grid mix } \\
1 \mathrm{kV}-60 \mathrm{kV} \text {, consump- } \\
\text { tion mix, at consumer, AC, } \\
1 \mathrm{kV}-60 \mathrm{kV}\end{array}$ \\
\hline Natural gas & 3.3 & 3.3 & 3.3 & $\begin{array}{l}\text { Process steam from natural } \\
\text { gas, consumption mix, at } \\
\text { plant, heat plant, } \mathrm{MJ}-\mathrm{SE}\end{array}$ \\
\hline Hard coal & 3.3 & 0 & 2.2 & $\begin{array}{l}\text { Natural resources from the } \\
\text { database based on data } \\
\text { from Gode et al. (2011). Coal } \\
\text { combustion }\end{array}$ \\
\hline Fuel gas condensation* & 11.3 & 11.3 & 11.3 & - \\
\hline Industrial waste heat* & 7.9 & 7.9 & 7.9 & - \\
\hline Total & 99.8 & 99.8 & 99.8 & \\
\hline
\end{tabular}

for the different sources of energy were found in the OpenLCA database. Fuel gas condensation and industrial waste heat were allocated to the processes in which they are by-products. Figures for the combustion of coal were not available in the existing database so these are made up of data according to Gode, et al. [48]. In the database, the combustion of wood-based materials includes biogenic carbon. Therefore, the source in the database was adjusted according to Gode, et al. [48] to exclude the biogenic carbon in the combustion stage for wood-based materials.

\subsubsection{Uncertainty analysis}

The uncertainties of LCI data in the LCA were analysed in this study. As a first step, a base case was simulated without any uncertainties being considered. This was then used as a reference value in the comparisons between cases when uncertainties were considered and when they were not. The next step was to assess the uncertainties of the LCl data by carrying out Monte Carlo simulations.

The Ecoinvent data quality system that is incorporated in the OpenLCA software was used in this study $[49,50]$. The quality system consists of a pedigree matrix (see Appendix 1) with five different parameters: reliability, completeness, temporal correlation, geographical correlation and further technological correlation. Each parameter is judged at five different levels. Level 1 corresponds to the data being well represented in the analysed case and level 5 where it is poorly represented. The different levels for each parameter are presented in Appendix 1. The uncertainty of each source of input data was judged according to the different parts of the matrix and how representative the data were for the analysed case. The assessed uncertainties for the energy sources used in 
this study are presented in Table 3, and the materials that were included are presented in Table 4. Each level of each parameter corresponds to an uncertainty factor, as presented in Appendix 1. From the uncertainty factors, the geometric standard deviation is calculated according to the Ecoinvent data quality system. The geometric standard deviations for each source of energy and material are presented in Tables 3 and 4. The distribution is set as a logarithmic normal distribution.

After assessing the uncertainties according to the matrix, Monte Carlo simulations were carried out to randomise the input values within the ranges given by the matrix. The number of iterations of the Monte Carlo simulations was decided by test running 250-10,000 iterations with an interval of 250 and assessing them graphically. The test was carried out for the Swedish district heating mix that is used in Sweden today as presented in Table 2. All case studies were run using the same number of iterations.

The results from the different numbers of iterations are presented in Fig. 2. At around 4000 iterations, the results begin to stabilise. A higher number of iterations does not result in a clearly more stable result due to the high uncertainties of the input values. The Pomponi, D'Amico and Moncaster [25] study also showed that at between 1000 and 10,000 iterations the results became steadier with a smaller spread between the different simulations.

A frequency diagram, in Fig. 3 for 4000 iterations shows the distribution of the results that is expected with a logarithmic uncertainty distribution.

The Monte Carlo simulation results were analysed mainly using the median, mean, 1 st quartile and 3rd quartile values. The whiskers and outliers are also presented in the results.

\subsection{Limitations}

This study focuses on the environmental aspects of a renovation measure and not its economic or social aspects. However, the measures that are analysed were based on measures that were, in fact, carried out in renovation projects in which both economic and social aspects were also considered [26]. This study will not perform any additional analysis of these aspects, but the results of this study could, in the discussion, be related to economic or social aspects performed earlier performed on the case studies.

The renovation measures are limited to the specific cases in which the renovations were carried out. Only one case was assessed for each renovation measure and each case only considered one option of materials, the materials that were used in the performed renovation. Only the potential energy reduction that was simulated or measured in earlier research, on the case studies, was used in this study.

SN Applied Sciences

A SPRINGER NATURE journal
The energy used for heating was limited to the Swedish average district heating mix.

In the research following the renovation with the ventilation system [26], the results from the study presented no differences in operational electricity use before and after the measure. It was assumed that the operational electricity use was not affected due to any of the renovation measures that were carried out.

In this study, the uncertainties of the input data are assessed. The uncertainties of the calculation method itself can also be carried out in the software but is not part of this study [51].

\section{Results}

For each renovation measure, the results of the two different energy scenarios, "Today's energy mix" and "Future energy mix", with and without consideration to the uncertainties, are presented. The simulation results are plotted in box diagrams in which the median, mean, 1st quartile (25th percentile), the 3rd quartile (75th percentile), whiskers and outliers are shown. The whiskers and outliers are not further analysed in this study because they do not influence the result. In the simulations in which the uncertainties were not considered, the boxes become lines as there was only one input value for each unit of input data and the simulation resulted in only one value. (The median, mean, 1 st quartile, the 3 rd quartile, whiskers and outliers all have the same value.)

\subsection{Installation of mechanical supply and exhaust air ventilation system with heat recovery}

The climate change potential due to the installation of supply ducts and an air handling unit with heat exchanger in a building with an existing exhaust ventilation system is presented in the middle two boxes in Fig. 4. The results of the climate change potential assessments when using "Today's energy mix" are presented in the first two boxes in Fig. 4. A decrease of 84 per cent, between the climate change potential when carrying out the measure or not, both with and without uncertainties, can be seen. The results of the climate change potential assessments when using the "Future energy mix" are presented in the last two boxes in Fig. 4. The results show, both with and without uncertainties, a decrease of 81 per cent when carrying out the measure. The simulation, with consideration to the uncertainties in the input data, shows that there is no overlap between carrying out the renovation and not carrying out the renovation when using both "Today's energy mix" and "Future energy mix". 


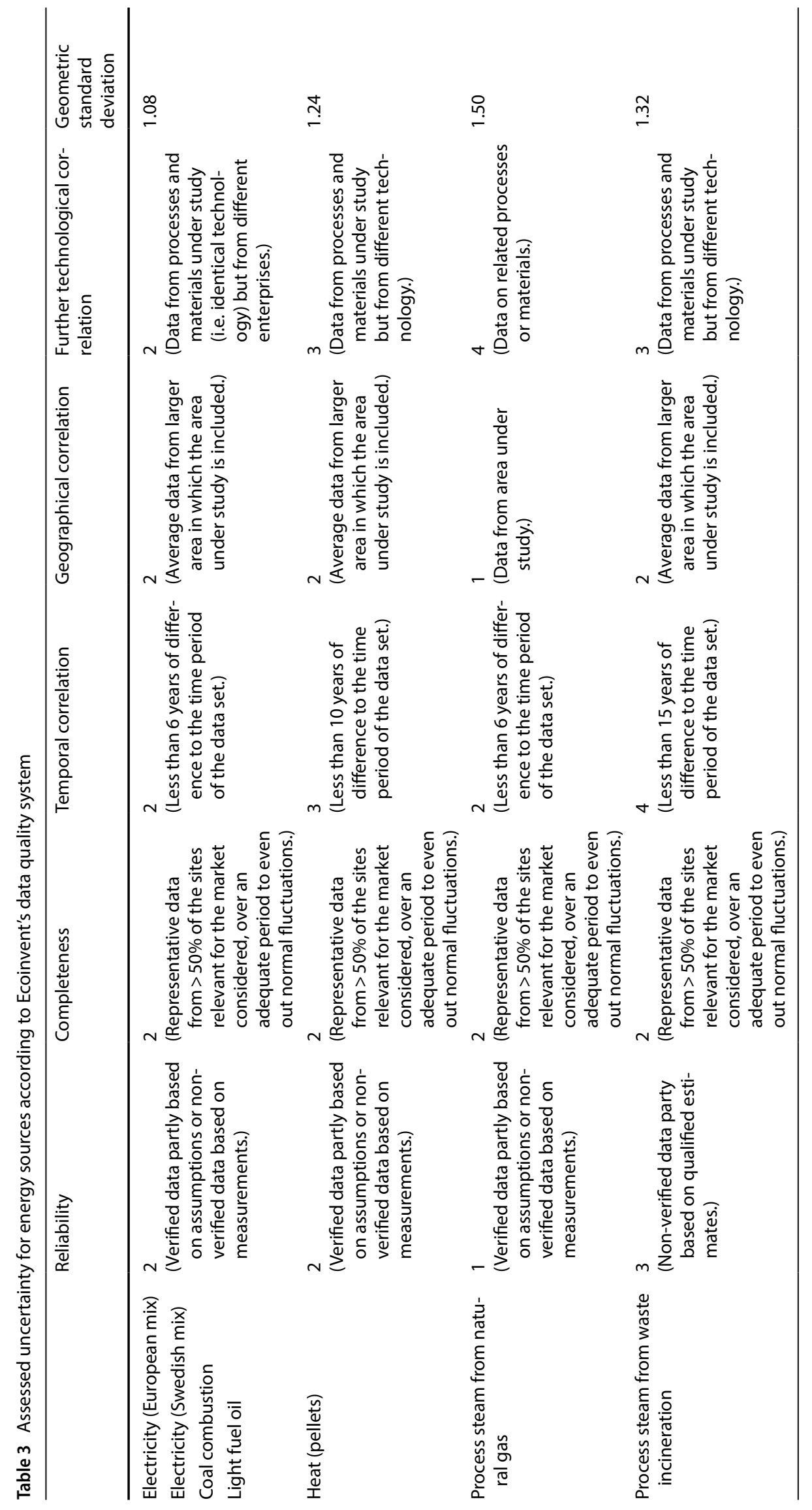


Table 4 Assessed uncertainties for material sources according to the Ecoinvent data quality system. For details regarding the levels, see Appendix 1

\begin{tabular}{|c|c|c|c|c|c|c|}
\hline & Reliability & $\begin{array}{l}\text { Complete- } \\
\text { ness }\end{array}$ & $\begin{array}{l}\text { Temporal cor- } \\
\text { relation }\end{array}$ & $\begin{array}{l}\text { Geographical cor- } \\
\text { relation }\end{array}$ & $\begin{array}{l}\text { Further technological } \\
\text { correlation }\end{array}$ & $\begin{array}{l}\text { Geometric } \\
\text { standard devia- } \\
\text { tion }\end{array}$ \\
\hline Steel & 3 & 2 & 2 & 2 & 2 & 1.12 \\
\hline Glass wool & 2 & 2 & 3 & 1 & 2 & 1.13 \\
\hline Aluminium & 2 & 2 & 3 & 2 & 2 & 1.13 \\
\hline Glass & 2 & 2 & 2 & 3 & 3 & 1.21 \\
\hline Wood (pine) & 2 & 2 & 3 & 3 & 2 & 1.13 \\
\hline Rock wool & 2 & 2 & 3 & 1 & 1 & 1.12 \\
\hline Cement fibre board & 2 & 2 & 3 & 2 & 4 & 1.52 \\
\hline Gypsum plaster board & 2 & 2 & 3 & 2 & 1 & 1.12 \\
\hline
\end{tabular}

Climate change potential

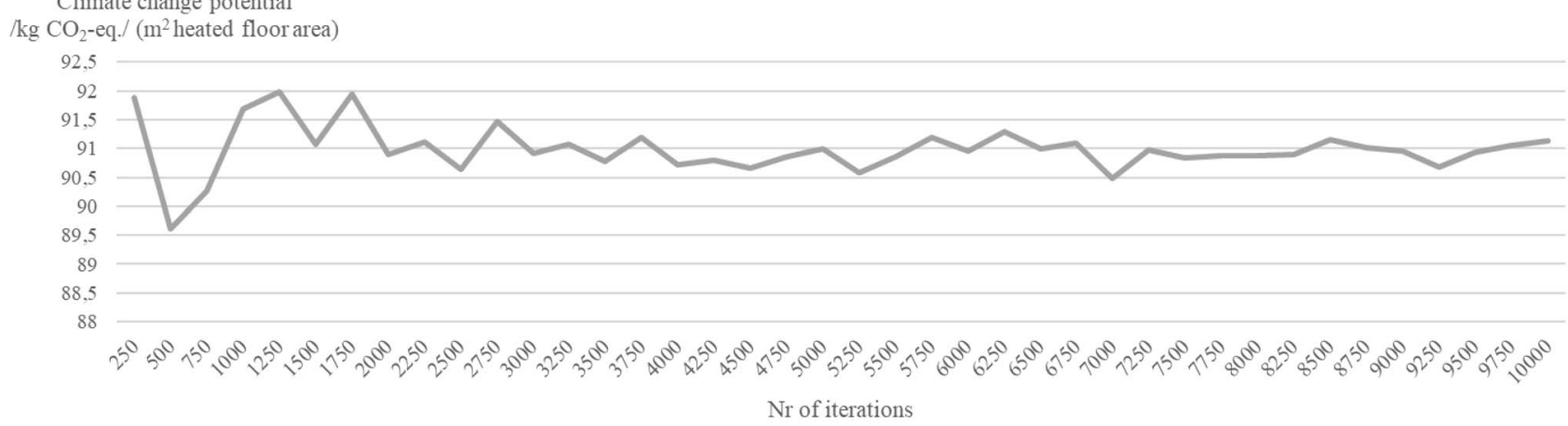

Fig. 2 Results from Monte Carlo simulations with 250-10,000 iterations

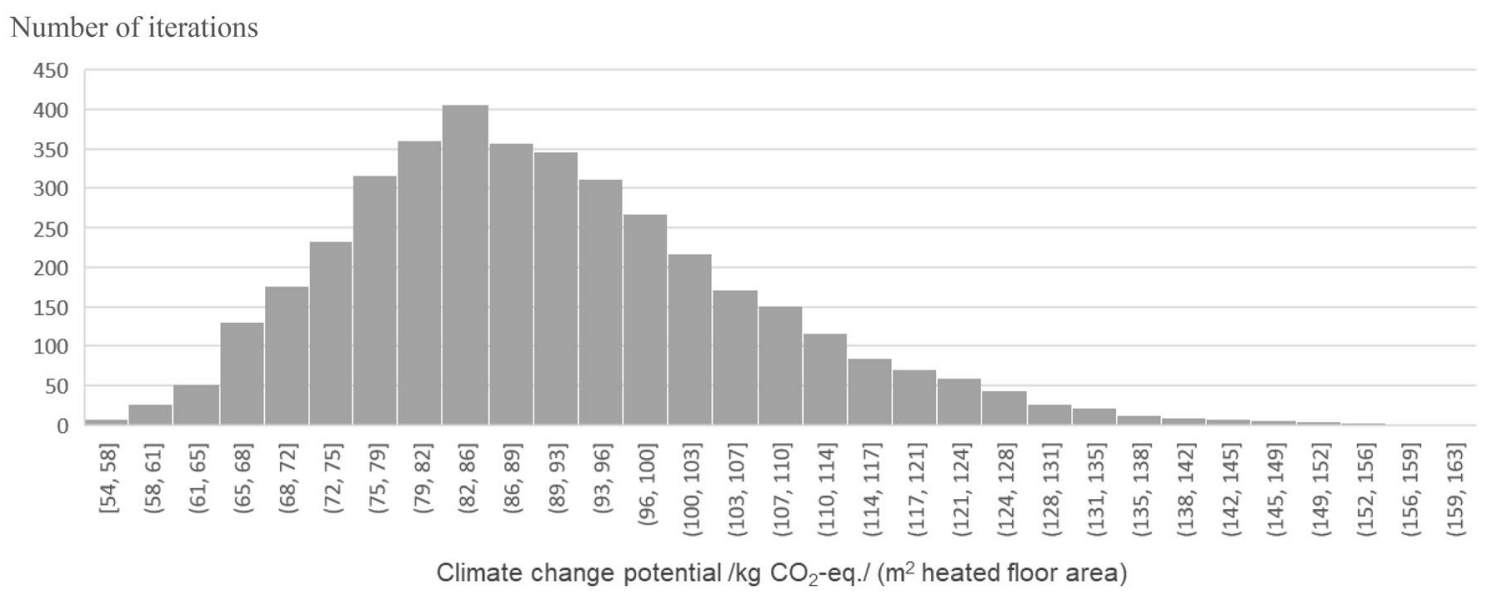

Fig. 3 Frequency diagram for 4000 iterations

\subsection{Attic insulation}

The climate change potential due to an additional $280 \mathrm{~mm}$ of insulation in the attics of the buildings is presented in the middle two boxes in Fig. 5. The results of the climate change potential analysis when the "Today's energy mix" is used are presented in the first two boxes in Fig. 5. A decrease of approximately 70 per cent, between the climate change potential when carrying out and not carrying out the renovation measure, both with and without uncertainty, can be seen. When the "Future energy mix" is used, the results are presented in the last two boxes in Fig. 5 .

\section{SN Applied Sciences}


Climate change potential

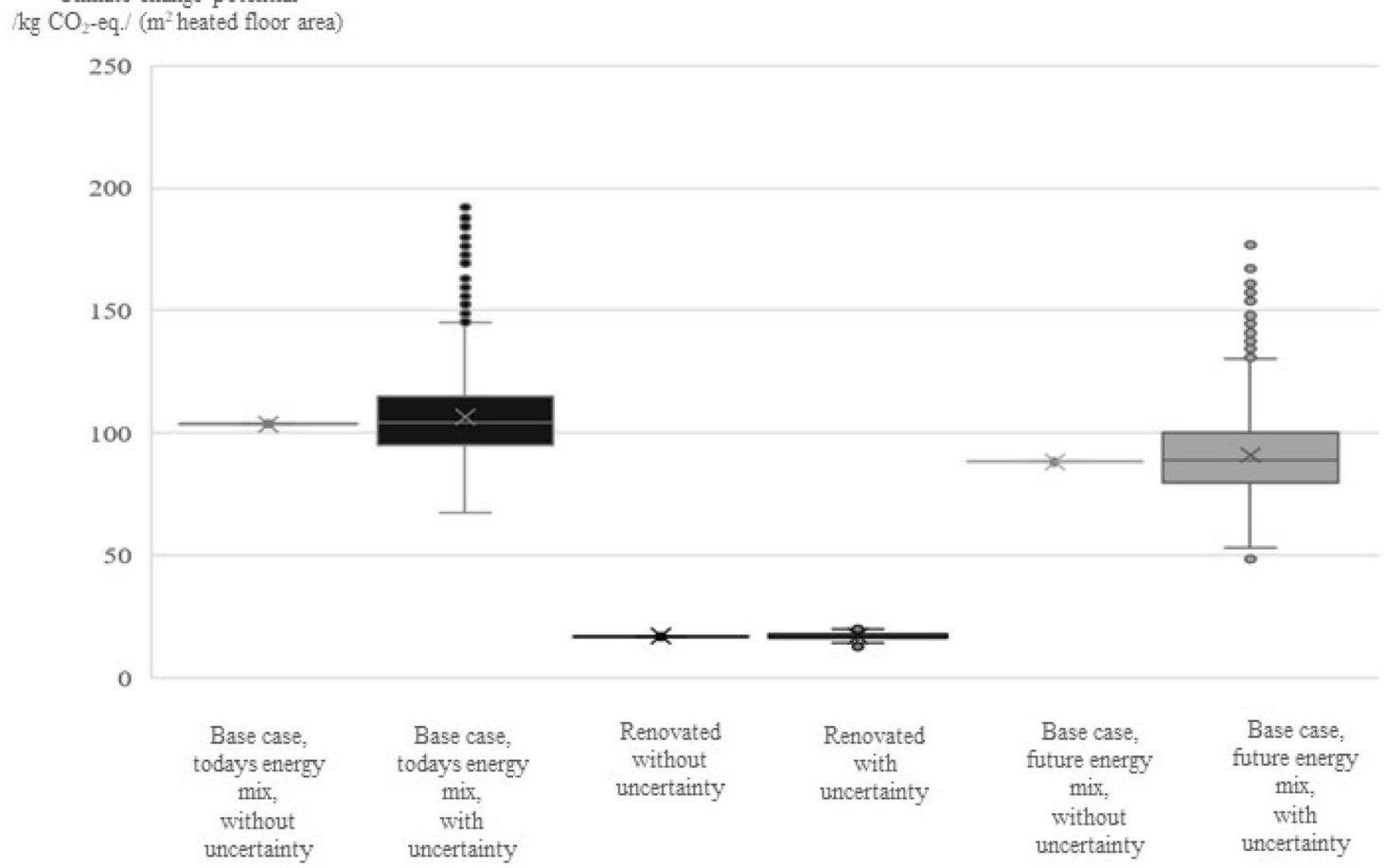

Fig. 4 Climate change potential of a building before and after the installation of a supply ventilation system and an air handling unit with heat recovery in a building with an existing exhaust ventila- tion system. Results are shown with and without consideration to the uncertainties in the input data and with two different scenarios for the energy mix

Climate change potential

$/ \mathrm{kg} \mathrm{CO}$-eq./(m² heated floor area)

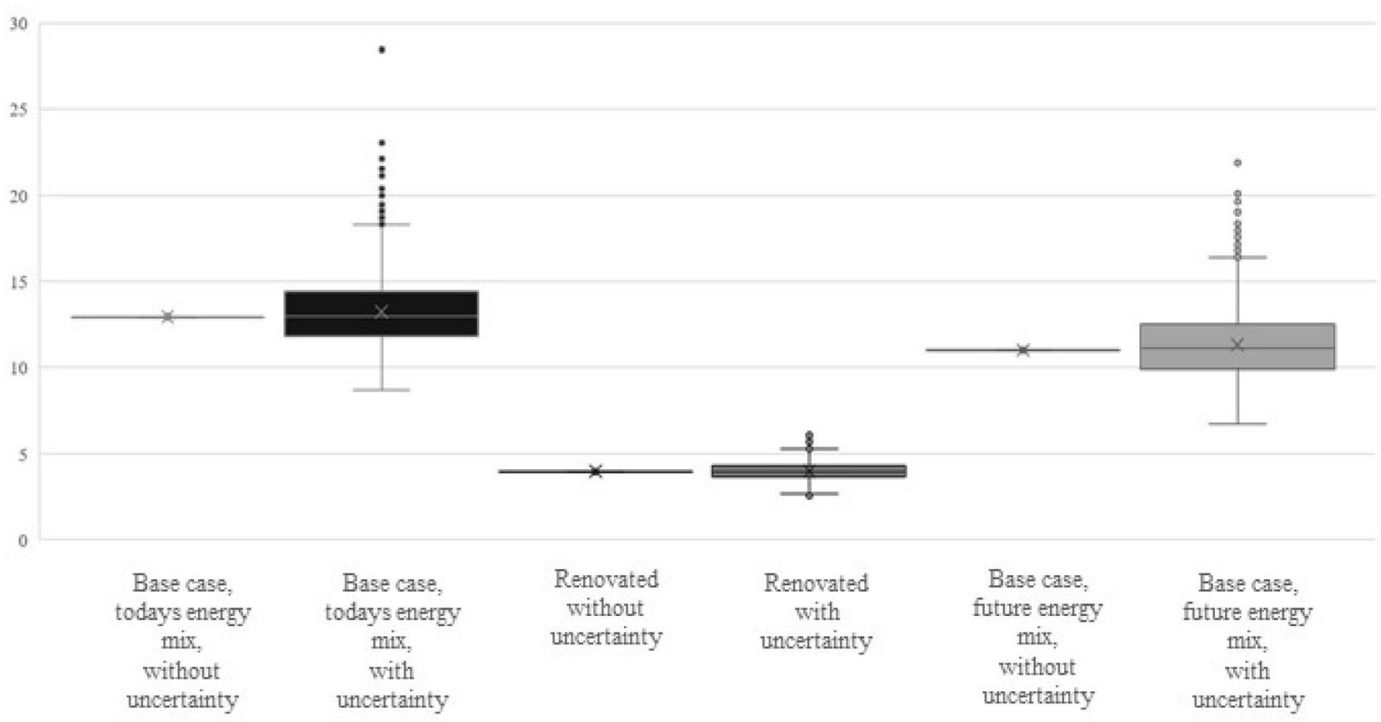

Fig. 5 simulation results for the climate change potential due to the addition of $280 \mathrm{~mm}$ of glass wool in the attics. The results are shown with and without consideration of uncertainties in the input data and with two different scenarios for the energy mix

Decreases of approximately 65 per cent, between the climate change potential when carrying out and not carrying out the renovation measure, both with and without consideration to uncertainty, can be seen. The simulations, with consideration to the uncertainties in the input data, show that there is no overlap between carrying out and 
not carrying out the renovation measure when using both the "Today's energy mix" and the "Future energy mix".

\subsection{Door replacement}

The climate change potential due to the replacement of all balcony doors on the ground and first floors in the buildings is presented in the middle two boxes in Fig. 6 . When the "Today's energy mix" is used, the results of the climate change potential assessments are presented in the first two boxes in Fig. 6 . The differences between the climate change potential when carrying out and not carrying out the renovation measure, both with and without uncertainty, show a decrease of approximately 80 per cent. When the "Future energy mix" is used, the results are presented in the last two boxes in Fig. 6 . The differences between the climate change potential when carrying out and not carrying out the renovation measure, both with and without consideration to uncertainty, show decreases of 77 per cent. The simulations, with consideration to the uncertainty of the input data, show that there is no overlap between carrying out and not carrying out the renovation measure for both "Today's energy mix" and "Future energy mix".

\subsection{Window replacement}

The climate change potential due to the replacement of all windows on the ground and first floors in the buildings is presented in the middle two boxes in Fig. 7. When the "Today's energy mix" is used, the results of the climate change potential assessments are presented in the first two boxes in Fig. 7. The differences in the climate change potential when carrying out the renovation measure, both with and without uncertainty, show a decrease of 96 per cent. When the "Future energy mix" is used, the results of the climate change potential are presented in the last two boxes in Fig. 7. The differences in the climate change potential when performing the renovation measure, both with and without uncertainty, show a decrease of 95 per cent. The simulations, with consideration to the uncertainty of the input data, show that there are no overlaps between carrying out and not carrying out the renovation measure for both "Today's energy mix" and "Future energy mix".

\subsection{Wall replacement}

The climate change potential due to the replacement of all the south-facing walls on the ground and first floors in the buildings is presented in the middle two boxes in Fig. 8 .

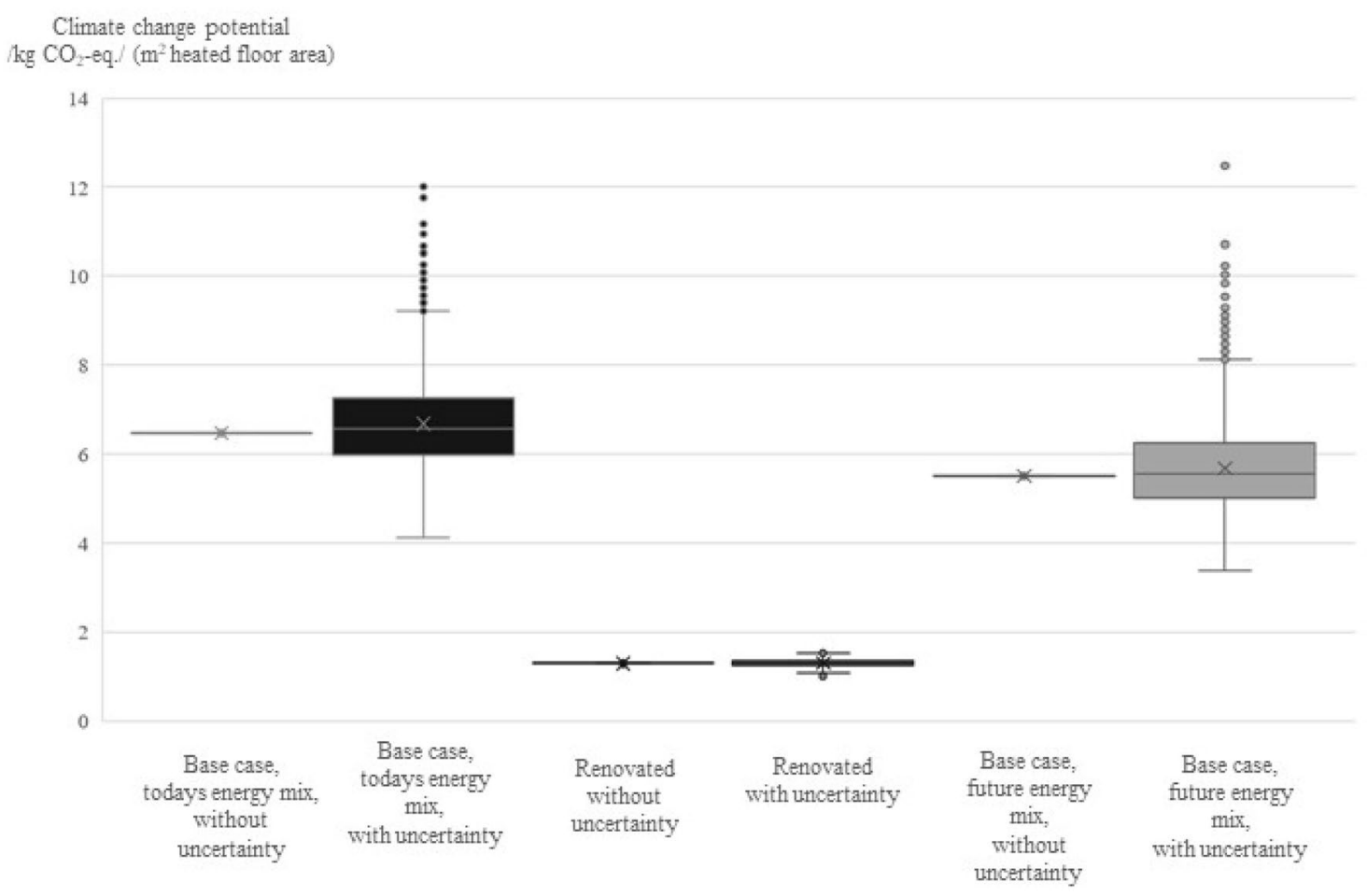

Fig. 6 Simulation results for the climate change potential due to the replacement of the balcony doors on the ground and first floors. The results are shown with and without consideration of uncertainties in the input data and with two different scenarios for the energy mix 
Climate change potential $\mathrm{kg} \mathrm{CO}$-eq./ (m² heated floor area)

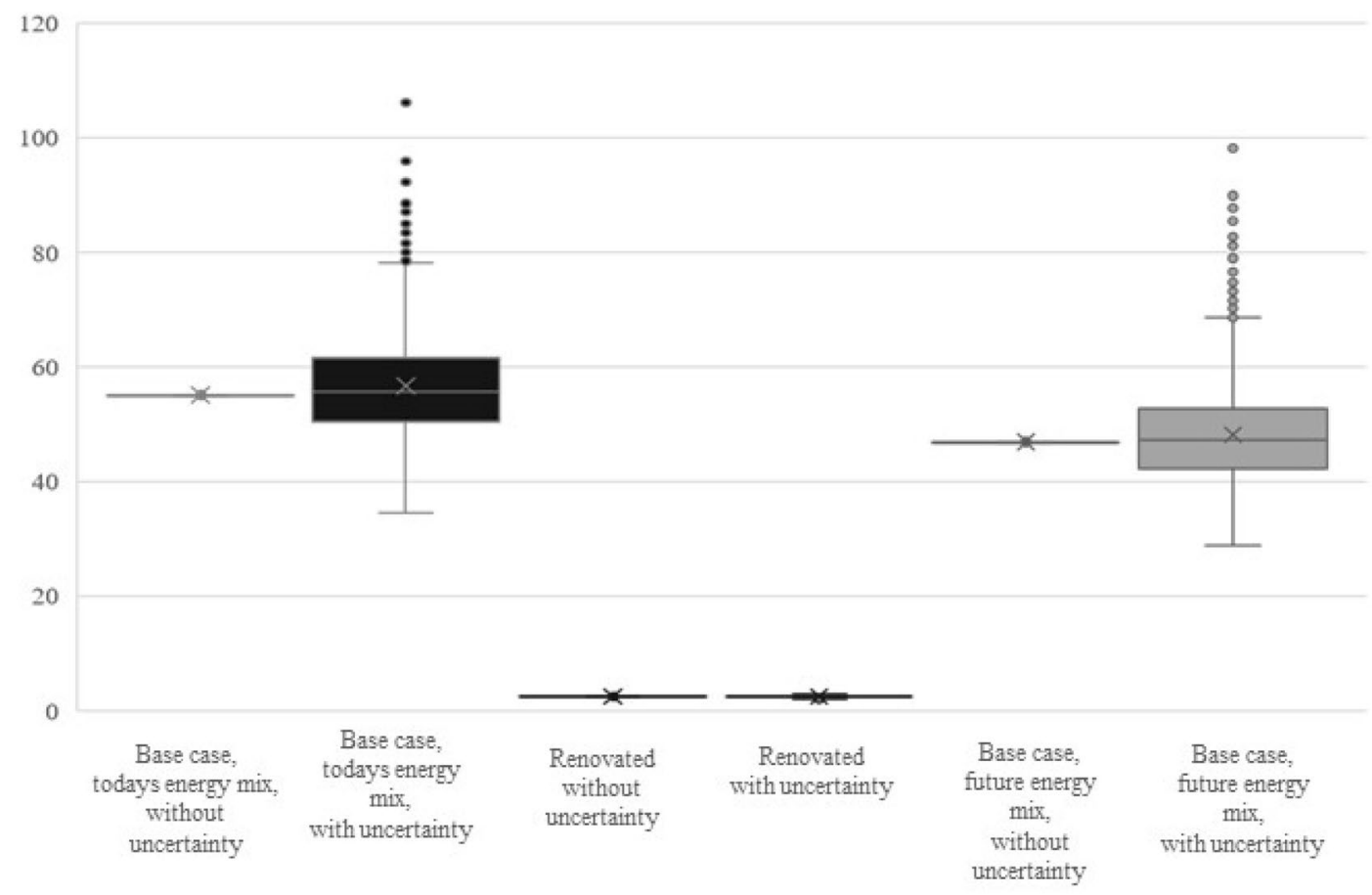

Fig. 7 Simulation results for the climate change potential due to the replacement the windows on the ground and first floors. Results are shown with and without consideration of uncertainties in the input data and with two different scenarios for the energy mix

Climate change potential $\mathrm{kg} \mathrm{CO}$-eq./ (m² heated floor area)

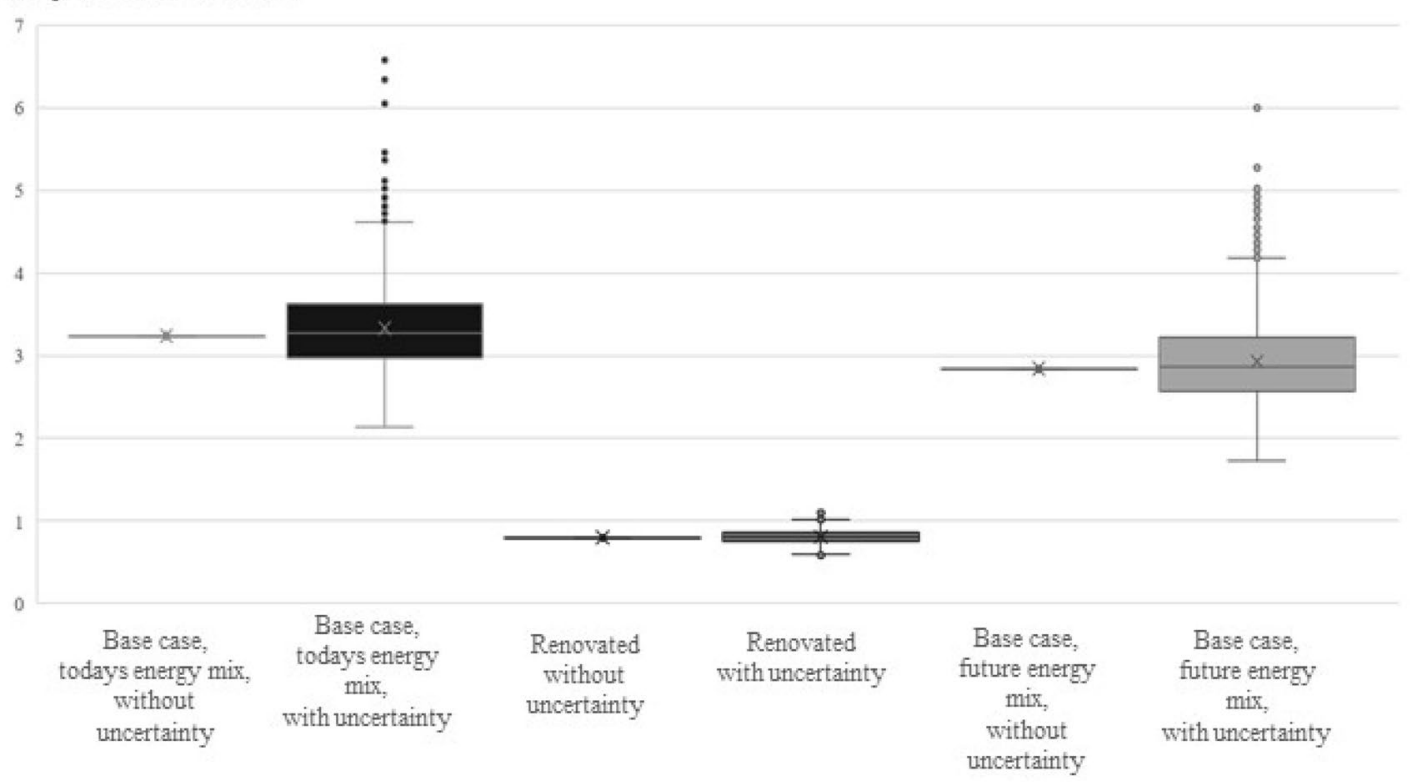

Fig. 8 Simulation results for the climate change potential due to the replacement of the south-facing walls on the ground and first floors. Results are shown with and without consideration of uncertainties in the input data and with two different scenarios for the energy mix 
When the "Today's energy mix" is used, the result of the climate change potential is presented in the first two boxes in Fig. 8. The differences in the climate change potential when carrying out the renovation measure, both with and without uncertainty, show a decrease of approximately 75 per cent. When the "Future energy mix" is used, the results of the climate change potential are presented in the last two boxes in Fig. 8. The differences in the climate change potential when carrying out the renovation measure, both with and without uncertainty, show a decrease of 72 per cent. The simulations, with consideration to the uncertainty of the input data, show that there are no overlaps between carrying out and not carrying out the renovation measure for both "Today's energy mix" and "Future energy mix".

\subsection{6 Summary of all renovation measures}

All renovation measures show a decrease in climate change potential when assessing the mean and median value when the "Today's energy mix" and "Future energy mix" are used in simulations as presented in Tables 5 and 6 .

The ranges between the first and third quartile show no overlapping in the results from before and after carrying out any of the renovation measures as presented in Table 5 for "Today's energy mix" and Table 6 for "Future energy mix".

\section{Discussion}

The uncertainties of the $\mathrm{LCl}$ input data were evaluated based on their reliability, completeness, temporal correlation (age), geographical correlation and further technological correlation. Both materials and energy sources were assessed for their uncertainties. These assessments were carried out for five renovation measures subject to two different energy mix scenarios. The study was limited to include the $A 1-A 3$ modules and the $B 6$ module of the life cycle analysis and were defined by the functional unit of $1 \mathrm{~m}^{2}$ of heated floor area of a renovated building.
Table 5 The 1st quartile to the 3rd quartile climate change potential for all renovation measures using the "Today's energy mix". The percentage differences in the climate change potential after carry- ing out a renovation compared to when no renovation is carried out using the "Today's energy mix" scenario are shown

\begin{tabular}{llllll}
\hline "Today's energy mix" & $\begin{array}{l}\text { No } \\
\text { uncer- } \\
\text { tainty } \\
(\%)\end{array}$ & $\begin{array}{l}\text { Median value } \\
\text { with uncertainty } \\
(\%)\end{array}$ & $\begin{array}{l}\text { Mean value } \\
\text { with uncer- } \\
\text { tainty (\%) }\end{array}$ & $\begin{array}{l}\text { Q1-Q3 no renovation (kg } \\
\text { CO2-eq./m² heated floor } \\
\text { area) }\end{array}$ & $\begin{array}{l}\text { Q1-Q3 with renovation (kg } \\
\text { CO2-eq./m² heated floor area) }\end{array}$ \\
\hline $\begin{array}{l}\text { Installation of mechanical } \\
\text { supply and exhaust air ven- }\end{array}$ & 83.6 & 83.7 & 84 & $95.2-115$ & $16.3-17.8$ \\
$\quad \begin{array}{l}\text { tilation with heat recovery } \\
\text { Extra insulation in attic }\end{array}$ & 69.3 & 69.5 & 69.9 & $11.8-14.4$ & $3.65-4.30$ \\
$\begin{array}{l}\text { Door replacement } \\
\text { Window replacement }\end{array}$ & 80.1 & 80.3 & 80.6 & $5.97-7.27$ & $1.24-1.35$ \\
Wall replacement & 95.6 & 95.6 & 95.7 & $50.5-61.6$ & $2.32-2.53$ \\
\hline
\end{tabular}

Table 6 First quartile to the 3rd quartile climate change potential for all renovation measures using the "Future energy mix". The percentage differences in the climate change potential after carry- ing out a renovation compared to not carrying out the renovation using the "Future energy mix" scenario are shown

\begin{tabular}{|c|c|c|c|c|c|}
\hline "Future energy mix" & $\begin{array}{l}\text { No } \\
\text { uncer- } \\
\text { tainty } \\
(\%)\end{array}$ & $\begin{array}{l}\text { Median value } \\
\text { with uncertainty } \\
(\%)\end{array}$ & $\begin{array}{l}\text { Mean value } \\
\text { with uncer- } \\
\text { tainty (\%) }\end{array}$ & $\begin{array}{l}\text { Q1-Q3 no renovation ( } \mathrm{kg} \\
\text { CO2-eq. } / \mathrm{m}^{2} \text { heated floor } \\
\text { area) }\end{array}$ & $\begin{array}{l}\text { Q1-Q3 with renovation ( } \mathrm{kg} \\
\mathrm{CO} 2-\mathrm{eq} . / \mathrm{m}^{2} \text { heated floor area) }\end{array}$ \\
\hline $\begin{array}{l}\text { Installation of mechanical } \\
\text { supply and exhaust air ven- } \\
\text { tilation with heat recovery }\end{array}$ & 80.7 & 80.9 & 81.3 & $79.8-100$ & $16.3-17.8$ \\
\hline Extra insulation in attic & 63.9 & 64.4 & 64.8 & $9.93-12.5$ & $3.65-4.30$ \\
\hline Door replacement & 76.6 & 76.7 & 77.2 & $5.01-6.26$ & $1.24-1.35$ \\
\hline Window replacement & 94.9 & 94.9 & 95 & $42.2-52.7$ & $2.32-2.53$ \\
\hline Wall replacement & 71.9 & 71.9 & 72.3 & $2.57-3.22$ & $0.75-0.86$ \\
\hline
\end{tabular}


The "Today's energy mix" is a "worst-case scenario" where there is no change from the energy mix that is used today. It is unlikely for the energy mix that is used today, to not change in the next 20 years, with both the European and national goals that are set up in today's society. Therefore, this study has performed the assessments with two different energy mix scenarios. If the goals are reached gradually, the "Future energy mix"- scenario gives a better representation of the future. Seeing into the future and assessing the energy mix that will be used in 20 years contribute to the high uncertainty that the results of these assessment show.

The results of the two different energy mix scenarios show a decrease in the climate change potential of 12-15.3 per cent when the average of the "Future energy mix" was compared to the average of the "Today's energy mix", due to the decreased use of fossil fuels. When considering the uncertainty of $\mathrm{LCl}$ input data, there is a large overlap between "Today's energy mix" and the "Future energy mix". Meaning that the climate change potential for the "Future energy mix" has a potential of being reduced compared to the "Today's energy mix" but with the uncertainties of the input data, this reduction also becomes uncertain.

For the five renovation measures, the simulations with and without consideration to uncertainties show a decrease in climate change potential between carrying out and not carrying out a renovation measure. When comparing the median and mean value with the "no uncertainty" value, the results show less than $a \pm 1$ percentage point difference in the climate change potential.

With consideration taken to uncertainties in the input data, the results show no overlapping between the results when carrying out and not carrying out a renovation measure, for all renovation measures.

Using the "Today's energy mix" scenario, the renovation measures with the greatest energy-saving potential (i.e. the ventilation and window replacement measures) are also the renovation measures with the greatest ability to decrease the climate change potential from a life cycle perspective. Ramírez-Villegas, Eriksson and Olofsson [17] also found that the more energy-effective measures had a greater potential to decrease the potential environmental impact.

All the results presented in Tables 5 and 6 show a potential decrease in the climate change potential. "Today's energy mix" shows larger differences between carrying out and not carrying out a renovation measure than the "Future energy mix".

The results show that all renovation measures will decrease the climate change potential, which implies that they should all be carried out regarding this perspective. If this is not shown to be the case, the "Future energy mix" will need to be further improved with regard to its climate change potential. In the "Future energy mix" scenario, the electricity part has been assumed to be highly improved and the goal of no fossil fuels by 2050 is assumed to be fulfilled. This implies that the remaining energy sources in district heating systems need to be improved from a climate change perspective.

In this study, focus has been on the uncertainties of the $\mathrm{LCl}$ input data. However, there are other uncertainties in the assessments that were not treated in this study. This study has only considered the current circumstances for the two existing neighbourhoods that were used for the case studies and only investigated the renovation measures that were actually carried out. The buildings had different geographical locations, differences in initial energy needs and slightly different shapes. A sensitivity analysis of other parameters would add to the uncertainties of the assessments that were carried out. Other building related parameters could include the uncertainties of the energy needs of the buildings and material choices as well as assumptions used in the analysis, such as the lifespan of different components.

The results of this study are not static over time. The sources of energy are expected to change due to the current goal to reduce the use of fossil fuels. How this development will evolve and how the set goals will be achieved or changed can only be assumed. Not only will the sources of energy change, the ways of producing building materials are also expected to evolve. This will affect both energy sources and developments in the manufacturing processes, transport and raw material extraction. Material properties will also be improved, which could lead to a lower demand for basic components.

In addition to other uncertainties in this study, there are also other environmental impact categories that could be considered. In this study, only the climate change potential has been included, but there are also other categories, such as eutrophication potential, acidification potential and ozone creation potential that could contribute to the assessment of the renovation measures.

When making a decision before a renovation measure, there are several aspects that need to be considered [26, $29,52]$. Assessing the climate change potential is one aspect that should be considered together with economic, social and other environmental aspects. An important factor that has been evaluated in these buildings is the indoor climate. The studies carried out show an increase in satisfaction among the residents in the buildings after carrying 
out the renovations. On a societal level, it is also important to bear in mind that no energy source is endless. Any energy-saving measure contributes to the societal goals of reducing our energy needs and, in the future, to the aim of only using renewable and fossil-free energy sources. In this study, only the energy needs from a life cycle perspective have been included.

The choice to carry out the life cycle assessments in OpenLCA was made as it provided an opportunity to carry out Monte Carlo simulations together with a more advanced data quality system from Ecoinvent as well as an opportunity to access the European database of $\mathrm{LCl}$ data and the ILCD method of calculating the climate change potential. Using a different database for the $\mathrm{LCl}$, a different method than the ILCD, as well as using a different data quality system, could influence the results.

Limiting the system boundaries to only include the $\mathrm{A} 1-\mathrm{A} 3$ modules and exclude the A4-A5 modules was done on the assumption that the A4-A5 input data would have a larger uncertainty than the input data in the A1-A3 modules. Including these stages would have increased the magnitude and uncertainty of the resulting $\mathrm{CO}_{2}$ equivalents. With a difference of climate change potential of more than 60 per cent, the risk of the A4-A5 modules influencing the overall conclusions was considered to be low.

\section{Conclusion}

This study shows that using the "Today's energy mix" and the "Future energy mix" all renovation measures result in a decrease in the climate change potential. The energysaving renovation measures with the largest climate change potential decrease were the ventilation and window replacement measures.

In this study, the inclusion of the uncertainties of the input data did not have any impact on the overall decisions to renovate or not. However, this should not be regarded as a general conclusion. If the renovation measure were to have a higher intensity of material or if the "Future energy mix" is improved further, the uncertainty consideration could become much more important from a climate change perspective.

Author's contributions The simulations were carried out by the first author with the support of the second author. All three authors contributed to the analysis of the results. The article was written by the first author under the supervision of the two other authors. This article is intended to be part of the first author's doctoral thesis.

Funding Open access funding provided by Lund University. This study has been financed by the Swedish National Board of Housing, Building and Planning and co-funded within the Strong Research environment SIRen [53], financed by Formas, a Swedish governmental research council. The authors have no relevant financial or nonfinancial interests to disclose.

Availability of data and material All data generated and analysed during this study are included in its supplementary information files.Code availability The simulations were carried out in the OpenLCA (version 1.9.0) open-source software using the freely available European reference Life Cycle Database of the Joint Research Center version 3.2 (ELCD) for $L C l$ information regarding materials and energy sources. The uncertainty analysis was carried out using the Ecoinvent data quality system available in OpenLCA.

\section{Declarations}

Conflict of interest The authors have no conflicts of interest to declare that are relevant to the content of this article.

Consent to participate Not applicable.

Consent for publication All data from the case studies have been approved for publication by building owners and authors of the previously carried out research projects. All figures and tables in this project were developed by the first author of this article.

Ethics approval Not applicable.

Open Access This article is licensed under a Creative Commons Attribution 4.0 International License, which permits use, sharing, adaptation, distribution and reproduction in any medium or format, as long as you give appropriate credit to the original author(s) and the source, provide a link to the Creative Commons licence, and indicate if changes were made. The images or other third party material in this article are included in the article's Creative Commons licence, unless indicated otherwise in a credit line to the material. If material is not included in the article's Creative Commons licence and your intended use is not permitted by statutory regulation or exceeds the permitted use, you will need to obtain permission directly from the copyright holder. To view a copy of this licence, visit http://creativecommons. org/licenses/by/4.0/.

\section{Appendix 1: The Ecoinvent data quality system}

The pedigree matrix used in the Ecoinvent data quality system is presented in Table 7.

Each level of uncertainty in the matrix presented in Table 7 corresponds to an uncertainty factor. Each level of uncertainty values is presented in Table 8. 


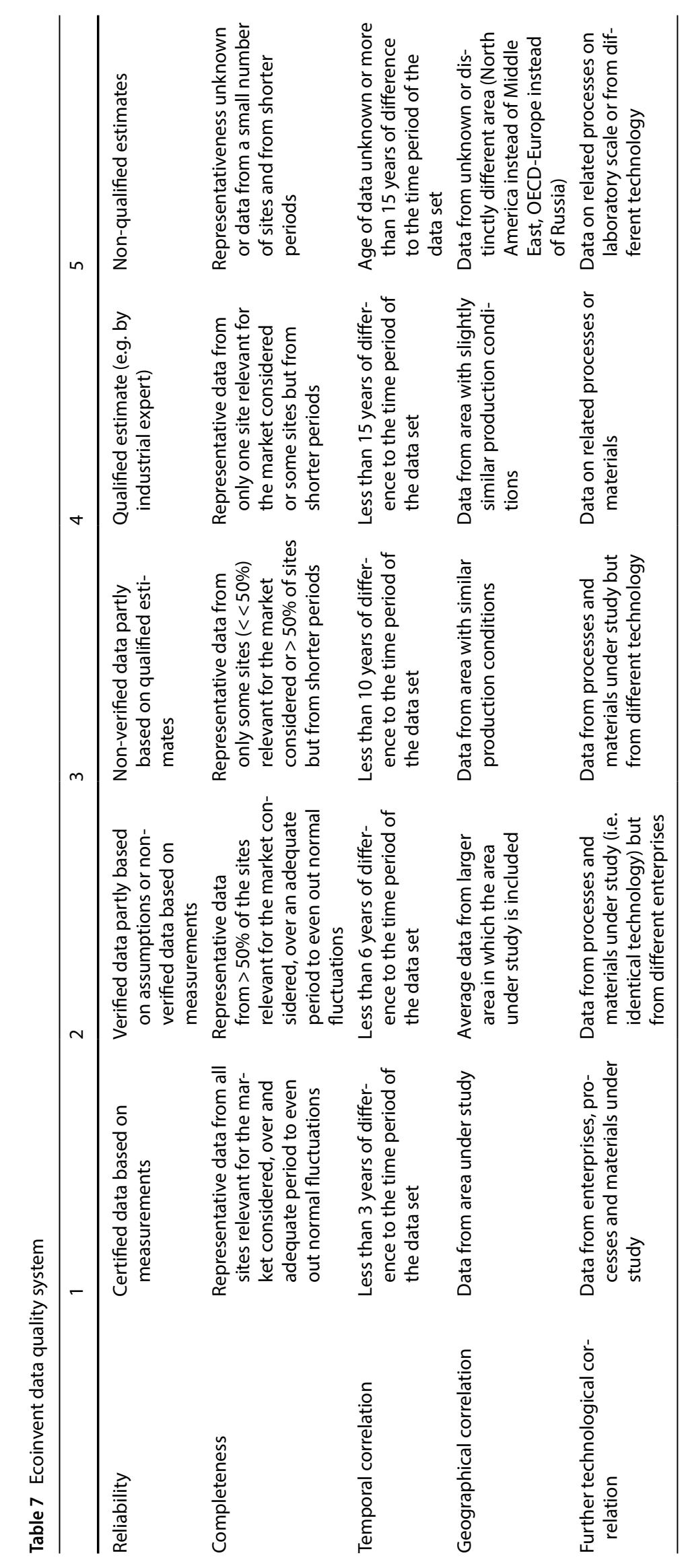


Table 8 Uncertainty factors for Ecoinvent data quality system

\begin{tabular}{llllll}
\hline & 1 & 2 & 3 & 4 & 5 \\
\hline Reliability & 1.0 & 1.05 & 1.1 & 1.2 & 1.5 \\
Completeness & 1.0 & 1.02 & 1.05 & 1.1 & 1.2 \\
Temporal correlation & 1.0 & 1.03 & 1.1 & 1.2 & 1.5 \\
Geographical correlation & 1.0 & 1.01 & 1.02 & 1.05 & 1.1 \\
Further technological correlation & 1.0 & 1.05 & 1.2 & 1.5 & 2.0 \\
\hline
\end{tabular}

\section{References}

1. European commission, "Renovation wave," 2020. [Online]. Available: https://ec.europa.eu/energy/topics/energy-efficiency/ energy-efficient-buildings/renovation-wave_en. Accessed 10 Mar 2021.

2. Eurostat statistics, "Eurostat," 2018. [Online]. Available: https:// ec.europa.eu/eurostat/statistics-explained/index.php/Green house_gas_emission_statistics_-_carbon_footprints.

3. European Commission (2020) Communication from the commission to the European parliament, the council, the European economic and social committee and the committee of the regions a renovation wave for Europe-greening our buildings, creating jobs, improving lives

4. Vilches A, Garcia-Martinez A, Sanchez-Montañes B (2017) Life cycle assessment (LCA) of building refurbishment: a literature review. Energy Build 135:286-301

5. The Swedish National Board of Housing Building and Planning (2016) Miljö- och klimatanpassade byggregler - Förstudie

6. Regeringskansliet Finansdepartementet (2020) "Klimatdeklaration för byggnader," Stockholm.

7. Swedish Institute for Standards (2018) SS-EN ISO 14044:2006/ A1:2018 Environmental managment - Life cycle assessment Requirements and guidelines-Amendment $1 . "$

8. Dossche C, Boel V, De Corte W (2017) Use of life cycle assessments in the construction sector: critical review. Procedia Eng 171:302-311

9. Swedish Institute for Standards (2012) “EN 15804:2012+a2:2019 Sustainability of construction works-Environmental product declarations-Core rules for the product category of construction products"

10. Hamid AA, Farsäter K, Wahlström $\AA$, Wallentén P (2018) Literature review on renovation of multifamily buildings in temperate climate conditions. Energy Build 172:414-431

11. Valčiukas $S$ (2012) Practice of multi-family housing renovations. comparative study of Stockholm and Vilnius on motivating, driving and bottleneck factors, pp 1-91

12. Itard L, Klunder G (2007) Comparing environmental impacts of renovated housing stock with new construction. Build Res Inf 35(3):252-267

13. Farsäter K (2019) “Evaluation of life cycle assessment tools for assessing the potential environmental impact of renovation measures. In: iiSBE forum of young researchers in sustainable building, pp 81-89

14. Olsson S, Malmqvist T, Glaumann M (2015) Managing sustainability aspects in renovation processes: interview study and outline of a process model. Sustainability 7(6):6336-6352

15. Mourão J, Gomes R, Matias L, Niza S (2019) Combining embodied and operational energy in buildings refurbishment assessment. Energy Build 197:34-46

16. Olsson S, Malmqvist T, Glaumann M (2016) An approach towards sustainable renovation-A tool for decision support in early project stages. Build Env 106:20-32
17. Ramírez-Villegas R, Eriksson O, Olofsson T (2019) Life cycle assessment of building renovation measures-trade-off between building materials and energy. Energies 12(3)

18. Swedish Institute for Standards (2006) SS-EN ISO 14040:2006 Environmental management-life cycle assessment-Principles and framework."

19. Scrucca F et al (2020) Uncertainty in LCA: an estimation of practitioner-related effects. J Clean Prod 268:122304

20. Emami $\mathrm{N}$ et al (2019) A life cycle assessment of two residential buildings using two different LCA database-software combinations: recognizing uniformities and inconsistencies. Buildings 9(1):1-20

21. Häfliger I-F, Viola J, Passer A, Lasvaux S, Hoxha E, SaadeMRM, Habert G (2017) Buildings environmental impacts' sensitivity related to LCA modelling choices of construction materials. J Clean Prod. https://doi.org/10.1016/j.jclepro.2017.04.052

22. Morales MFD, Reguly N, Kirchheim AP, Passuello A (2020) Uncertainties related to the replacement stage in LCA of buildings: a case study of a structural masonry clay hollow brick wall. J Clean Prod 251:119649

23. Groen EA, Bokkers EAM, Heijungs R, de Boer IJM (2017) Methods for global sensitivity analysis in life cycle assessment. Int J Life Cycle Assess 22(7):1125-1137

24. Pannier ML, Schalbart P, Peuportier B (2018) Comprehensive assessment of sensitivity analysis methods for the identification of influential factors in building life cycle assessment. J Clean Prod 199:466-480

25. Pomponi F, D'Amico B, Moncaster AM (2017) A method to facilitate uncertainty analysis in LCAs of buildings. Energies. https:// doi.org/10.3390/en10040524

26. Kristoffersson J, Bagge $H$, Abdul Hamid A, Johansson D, Almgren $M$, Persson M-L (2017) Användning av värmeåtervinning i miljonprogrammet. https://www.e2b2.se/library/3686/slutrapport_anvan dning_av_varmeatervinning_i_miljonprogrammet_webb.pdf

27. Pedersen E, Borell J, Li Y, Stålne K (2021) Good indoor environmental quality (IEQ) and high energy efficiency in multifamily dwellings: How do tenants view the conditions needed to achieve both? Build Environ 191:107581

28. Pedersen E, et al. (2020) “Hitta balansen ! Boende, innemiljö och energi," Swedish Energy Agency

29. Sellin N, Magnusson R (2018) Renoveringsåtgärders och brukarbeteendes effekt på energianvändning och inomhusmiljö $\mathrm{i}$ frånluftsventilerade flerbostadshus-En fallstudie av miljonprogramhus i Lund. Lund University

30. Stålne K, Pedersen E (2021) Transdisciplinary research on indoor environment and health as a social process. Int J Environ Res Public Heal 18(8):4379

31. Högdal K (2013) Halvera Mera-Slutrapport. BeBo, Stockholm

32. Hamid AA, Bagge H, Johansson D, Kristoffersson J (2018) Installation av FTX i miljonprogramshus-Analys av energibesparing och inneklimat. Lund University, Lund

33. ASHRAE (2013) ASHRAE equipment life expectancy chart

34. Fläkt Woods (2011) Tilluftsdon CTVB

35. Klimatbyrån (2015) BYGGVARUDEKLARATION BVD 3

36. Swegon (2020) Building product declaration 2015 Casa R15H Smart

37. Svenska Fönster AB, Pantze A, Lindbäck E, Bohlin I, Adolfsson I, Myndes P (2020) “EPD Wood- and wood aluminum clad windows and patio doors

38. Dodd N, Cordella M, Traverso M, Donatello S (2017) “Level(s)A common EU framework of core sustainability indicators for office and residential buildings Part 3: how to make performance assessments using Level(s) (Draft Beta v1.0)," Sevilla

39. Ciroth A (2007) ICT for environment in life cycle applications openLCA-a new open source software for life cycle assessment. Int J Life Cycle Assess 12(4):209-210 
40. GreenDelta GmbH, “openLCA," 2014. [Online]. Available: www. openlca.org. Accessed 23 Jul 2015

41. European Commission and Joint Research Centre (2012) Characterisation factors of the ILCD recommended life cycle impact assessment methods: database and supporting information

42. Cabeza LF, Rincón L, Vilariño V, Pérez G, Castell A (2014) Life cycle assessment (LCA) and life cycle energy analysis (LCEA) of buildings and the building sector: a review. Renew Sustain Energy Rev 29:394-416

43. Swedish Institute for Standards (2011) SS-EN 15978 Sustainability of construction works-assessment of environmental performance of buildings-CALCULATION method

44. Ventistål AS (2020) EPD Sirkulære ventilasjonskanaler

45. Dahlblom (2020) Towards sustainability with building services systems - by focusing on material choices, energy use and thermal indoor climates in residential buildings. Lund University

46. Energiföretagen, "Fjärrvärmens bränslemix," 2019. [Online]. Available: https://www.energiforetagen.se/globalassets/ energiforetagen/statistik/fjarrvarme/tillford-energi/fjarrvarme ns-branslemix-2017.pdf?v=FVUfkrfIJfYbp34Vdndo4Z1gvaY. Accessed 02 Jul 2020

47. Energimyndigheten (2016) Fyra framtider-Energisystemet efter 2020
48. Gode J, Martinsson F, Hagberg L, Öman A, Höglund J, Palm D (2011) “Miljöfaktaboken 2011, Uppskattade emissionsfaktorer för bränslen, el, värme och transporter [Estimated emission factors for fuels, electricity, heat and transport in Sweden].

49. Muller S, Lesage P, Ciroth A, Mutel C, Weidema BP, Samson R (2016) The application of the pedigree approach to the distributions foreseen in ecoinvent v3. Int J Life Cycle Assess 21(9):1327-1337

50. Ciroth $A$, Muller $S$, Weidema B, Lesage $P$ (2016) Empirically based uncertainty factors for the pedigree matrix in ecoinvent. Int $J$ Life Cycle Assess 21:1338-1348

51. Ciroth A, Fleischer G, Steinbach J (2004) Uncertainty calculation in life cycle assessments: a combined model of simulation and approximation. Int J Life Cycle Assess 9(4):216-226

52. Farsäter K (2017) Sustainability aspects in renovation-information supporting early decisions made by building owners. Lund Univarsity

53. Swedish National Renovation Centre, "SIRen," 2017. [Online]. Available: www.renoveringscentrum.Ith.se/siren. Accessed 18 Jan 2017.

Publisher's Note Springer Nature remains neutral with regard to jurisdictional claims in published maps and institutional affiliations. 